\title{
EVALUATION OF ENVIRONMENTAL QUALITY COMPONENTS ON SATISFACTION, DELIGHT AND BEHAVIOR INTENTIONS OF CUSTOMERS (CASE STUDY: GORGAN RESTAURANTS)
}

\author{
Mansour Yeganeh \\ Assistant Professor, Architecture Department, \\ Art and Architecture Faculty, TarbiatModares University, \\ Tehran, Iran. Yeganeh@modares.ac.ir \\ Fatemehbaygi \\ M.A in Architecture, Architecture Department, \\ Art and Architecture Faculty, TarbiatModares University, \\ Tehran, Iran. fatemebg@gmail.com \\ AzadehSargazi \\ M.A in Architecture, Islamic Azad University Gorgan, \\ Tehran, Iran. Azadesargazi68@gmail.com
}

\section{http://dx.doi.org/10.26739/2573-5616-2018-3-2-10}

\begin{abstract}
: todaysatisfaction of customersand their behavior intentions are considered as an important competitive advantage in dynamic environments. Researchers have proposed the concept of satisfaction, delight customer and behavioral intentions as an important criterion of marketing success. The restaurant industry is not excluded from this relationship.One of the important things that make sense of satisfaction, delight and behavior intentions in customers is to pay attention to the quality of the physical environment of the restaurantsbecause the restaurant is one of the most important places in the service sector and it affects to the perception of thousands of customers and domestic and foreign passengers. Therefore, the present study sought to investigate the effect of the quality of the physical environment of the restaurant on the satisfaction, delight and behavior intentions of customers. This research has been studied based on descriptive-analytic and survey method has And Research tool is aquestionnaire. Case studies are two restaurantin Gorgan, and the statistical community is the customers of these restaurants, which 384 people have been studied.Research findings show that green space factor has the most impact on customer satisfaction.
\end{abstract}

Key words: satisfaction, delight, behavior intentions, environmental quality.

\section{Introduction}

In today's competitive world, companies need to pay more attention

to customers and meet their needs (better than competitors) to gain more advantage. On the other hand, customers have different trend in getting products that makes companies to pay more attention to set 
marketing strategies. Customers need different services that makes it possible for to vary in ratios of satisfaction and behavior intentions of customers (Brady and Cronin, 2001).

Customer satisfaction is a ratio of customer's sense of satisfaction with the provision of services(Deng et al, 2010).The concept of satisfaction refers to a wide range of trends and intentions to meet the basic needs of humans (Gifford,1999). Customer satisfaction is the ratio to which the customer is positive towards the service provider(Deng et al, 2010). But services provided needs less satisfaction than customer satisfaction. As a matter of fact, customer expectations from delivering services leads to customer satisfaction, while the customer's delight in delivering services is beyond the customer's expectations(Torres and Kline, 2006).Costumer behavior intentions is a deep obligation toward buying a product or getting a service in the future that makes costumers to buy from similar brand and have a potential to change their behavior (Oliver, 1999). Increasing customer behavior intentions has always been a concern for managers (Westbrook, 1987) because buying products in the future is a result of behavior intentions.In particular, behavior intentions are defined as the tendency to buy from a store repeatedly (Keating et al, 2003; Flavin et al, 2006).

The restaurant industry has realized that paying attention only to the quality of food cannot be a factor in their success, as more detail needs to be looked at, such as the environment(Reuland et al, 1985).Influence of environment on user perception is one of the main issues in studying environment subject. In recent years, environment and its influence on daily life of people have been an issue for professionals (Canter, 1997).

Making a good relation between human and surrounding environment is being one of the missions for designers and architects. Designers and architects need to have a proper understanding of a human behavior in different environments, in order to gain this goal, so that it makes the relation between human and place stronger (Waxman, 2004). One of these places is restaurants. Restaurants are a vital and important part of a country or city. In fact, the restaurant is a place to relax and guests welcoming who serve their own specialties and have a significant impact on the attraction of customers and tourism (Abolhasani et al, 2011).

Basic needs of a tourist must be met, in addition to the places he wanted to visit when he travels.

One of the attraction for tourism is food as the basic of human physiological. One of the means of spending a leisure time for tourist is eating, being in a restaurant or similar places, such as coffee shops, teahouses and etc. the role and attraction of food services is increased as culture differences between tourist land and the visited place, especially if the provided food being served in a well quality environment and appropriate 
with the culture of the place (Ranjbarian andzahedi, 2000). As a result, the design of the quality of the environment needs to be in a way that have emotional influence on costumers, so that increases being in the place and will result satisfaction, delight and behavior intentions, that is a key factor to shape the relation between users and the environment, and ultimately makes a better creation of environment quality (Ruy et al, 2012).

Reviling the place is one the architect duty.In fact, the place is given with the building. Architectural art is the creator of the creative task of collecting and displaying the properties of the environment.In fact, the architect places the human being where the existence of a human being is an intrinsic place.As a result of this issue, the architect must devise a plan to revitalize human beings, taking into account the ontological characteristics of humans and the particular attention to human existence (Safian et al, 2011).

The purpose of this study was to evaluate the quality of environmental factors on satisfaction and delight and behavior intentions of customers. One of the research goals is to examine the contribution of environmental quality factors to satisfaction and delight and behavior intentions of customers.In this regard, the following two fundamental questions have been intended to be answered:

1- Is there a meaningful relationship between the quality of the environment and satisfaction and delight and behavior intentions?

2- Which of the factors affecting the quality of the environment affect the satisfaction and delight and behavior intentions of the people in the restaurants?

The answer to these questions shows the importance and necessity of such studies more than before, because addressing such research plays an important role in providing solutions to designers and architects in order to maintain and enhance the satisfaction and delight and behavior intentions of customers.

\section{Research Basics}

\section{Environmental quality}

The restaurant is a place to relax and welcoming guests, who serve with their own specialties (Abolhasani et al, 2011) The restaurant industry players realized that attention to food quality could not be a factor in their success, but more details need to be considered, such as the physical environment and staff (rafaati et al, 2014). Hence, in past studies, the importance of changing the quality of the physical environment in the restaurant industry has been emphasized.

Defining of environment is difficult as architects, psychologists, sociologist and geographers have different definition in their own field. 
Environment is a complex concept which have different dimensions. Important aspects of it are space data, social, cultural, physical, architectural, symbolic, geographic, historic and biological (Mortazavi, 2001). The environment literature distinguishes between varied words, physical environment, social environment, psychological environment, and behavioral environment. The key issues to these categories is to make a difference between real or objective worldthat would affect behavior or mental reaction of human consciously or unconsciously. In architecture field, surrounding area is a main definition of environment. So considering surrounding areas must be related to any definition, description or explanation of the environment (Emamgholi et al, 2012). The physical environment involves all physical and inhuman aspects of the context in which costumer behavior occurs. The physical environment can be classified into two categories of spatial and non-spatial elements. Types of physical components, such as product, and business names, shops and interior designs are included in spatial elements; non-spatial elements are the intangible ones, including temperature, humidity, brightness and sound level (Olson et al, 2002). Many researchers have identified environmental conditions as a factor influencing human perceptions and reactions against the environment and as a general rule, it can be said environmental conditions affect all five senses of man (Yunkyone Kim, 2007).

\section{Customer Satisfaction}

Studies in the field of satisfaction will cover a wide range of customer satisfaction from services provided by an organization, life satisfaction, residential satisfaction, etc. Satisfaction and dissatisfaction can be considered as an emotional response given to the evaluation of the goods or service that is being used or provided (Soltani and Sharif, 2015).

Costumer is who buy or a service as a traditional point of view, while as being someone who the company wants to influence by creating values is a better definition (Nazemi andSaadatyar, 2013). In fact, it's not the customer that needs the company, but the company that needs it. He is the target of all the company's work and part of the company's business. The company does not do the work for him, he will be grateful to the company and give the company the opportunity to serve him (Sadrinia andShirazi, 2008).

Peter Drucker gives the most complete and comprehensive definition of costumer and business. "If you want to know the concept of a business, you must start with its goal, there is only one valid definition of the purpose of the business, the creation of the customer," he says. The customer is the one who determines what a trade is, which is what the client thinks and what he considers worth considering. Foundation of the any business is a costumer and he is the one makes the trade alive and also creates 
employees (Amirshahi et al, 2009). Looking at the subjects from costumers' point of view becomes companies and organization's philosophy to create their roles.

In relation to the concept of customer satisfaction, different definitions have been provided by theorists; customer satisfaction is the perception or trend of a customer to a product or service after use (Jamal andNaser, 2002). Customer satisfaction is the enjoyment and disgust of the buyer in relation to product and service performance, after comparing the performance (or result of the operation) of the product or service purchased in comparison with what he was expecting (Cutler andArmstrong, 2007). Also, Cutler, elsewhere, mentioned satisfaction of the customer as the ratio to which a company's actual performance meets customer expectations. In his opinion, if the company fulfills customer expectations, the customer feels satisfied and otherwise feels dissatisfied (Haghighi et al, 2003).Satisfaction with other relevant concepts, such as quality, loyalty, and attitude, is different in literature and has been hypothesized to have a direct impact on customer loyalty and re-purchasing behaviors and purposes (Caruana, 2002).

Due to the various characteristics of the product and being a source of profitability and a reason for company to continue working is by customer satisfactionCustomer satisfaction is the feeling or attitude of the costumer towards products or services affecting costumer behavior in buying products. Costumers would buy more and continuously if they are satisfied by a product or services they get. Customers are happy with other people about their desirable experiences and the outcome of these conversations is a kind of mouth-to-mouth advertising for the company(Ryu and Jang, 2007).

The concept of satisfaction refers to a wide range of tendencies and intentions to meet the basic or transcendental needs of humans. Selecting and supplying many of the needs form lees likely located places (Gifford,1999). Satisfaction is the perceived result that a person acquires on the basis of positive environmental assessment and individual experience of his or her community, which leads to physical health, social, organic, and mental health (Dozdozani et al, 2015).

Campbell (1986) defines satisfaction as the difference between what one wants and what it achieves (Potter\&Cantarero, 2006: 606). Referring to this, it can be said that satisfaction is a big concept which have been examined and evaluated among various fields (Mozaffari et al, 2016). So that some researchers point of view considers satisfaction as a common factor to evaluate the percentage of desirability of perceived quality from environment( $\mathrm{Ha} \&$ Weber, 1994). The satisfaction of turning from objective to subjective issues, that is, evaluating what is mentally or internally and the ratio of their compliance with previous standards (Pendar andZekavat, 2016).

Satisfaction is a consequence of positive emotions and attitudes towards 
the position of people in the community, which leads to positive attitude to physical health, social, organic, and mental health, and can lead to a higher ratio of social commitment, which has an attitude Constant and loyal to society (Galbraith, 1992).

A satisfied person can, while satisfying, be able to adapt to unpleasant factors and environmental pressures.So pleasure can lead to compatibility, but compatibility does not necessarily lead to satisfaction (Ghiasvand , 2011: 33-37).That is, acceptance of hard social conditions does not necessarily represent satisfaction and real calmness in the society, but rather reflects the adaptive behavior to control the conditions until it is exhausted. If this behavior is prolonged, then consequences such as behavioral agility, dissatisfaction and consequently aggression and even death can happen (Galbraith, 1992).

\section{Costumers Delight}

Delight is defined as a positive emotion that the customer would gain while getting a service is better than what he expected (Al-Hawari, 2001), customer satisfaction should go more than services provided. In fact, what costumer gets from services is satisfaction, while what he gets more beyond expectation is delight (Torres \& Kline, 2006).

\section{Costumer behavior intentions}

Although it's been more than 70 years that thought about behavior intentions have been raised, but scientific progress have been limited. Efforts to create theoretical views that can bring new life into behavior intentions' research are scaled up by researchers (Safazadeh, 2011). The cognitive science, and in particular the branch of attitudes, provides a way to justify the literature of loyalty in management (Dick andBasu,1994).

Several associate literatures (such as psychology, organizational behavior, sociology, and marketing) show that the tendency to change brands and oral advice to purchase have some backgrounds that originate from social exchange theory. The tendency to change brand and oral advice to purchase based on two motivations are hypothesized:

1-A theory based on past experience that evaluates the benefits the customer receives from the relationship.

2- A future-oriented hypothesis that considers other resources for maintaining the relationship (Sweeny and Swait, 2008).

Mental judgments about people behavior in the future is what called behavior intentions (Tsaur et al, 2007: 51). Soderland and Ohhman in 2005, was first gives a definition to behavior intentions as being expectations and needs which have a positive relation with people satisfaction (Keng, 2007: 353).Costumer's dissatisfaction and satisfactions with the product affects its subsequent behavior.If the costumer is satisfied with the product, the likelihood of re-purchasing increases. 
On the other hand, the reaction of dissatisfied customers also varies and may lead to internal and external reactions (Nazemi andSaadatyar, 2013).According to Zeitamel et al (1996), participating or leaving the company indicates by costumer behavior intentions. Behavior intentions can be classified in two desirable and undesirable ways. Desirable behavior intentions include positive word of mouth advertisements, paying extra, spending more money on the company, and staying loyal to the company. Conversely, undesirable behavior intentions include leaving the company, spending less money on the company, developing negative wordings and carrying out legal activities against the company (Ladhari, 2009).Findings by Anderson and Sullivan (1993) show that greater customer satisfaction reduces the perceived benefits of changing service providers, increasing customer re-purchasing intentions. All of these findings confirm the relationship between customer satisfaction and customer behavior intentions (Anderson and Sullivan, 1993).Totally, considering customer satisfaction as the first step to attract him, the next step would be the creation of delight that gives him services more than he expect.Final and important step is customer behavior intentions which leads to make him buy more and use product or a restaurant again, and makes the customer remain loyal to the chosen restaurant. In Figure 1, a model is presented as described.

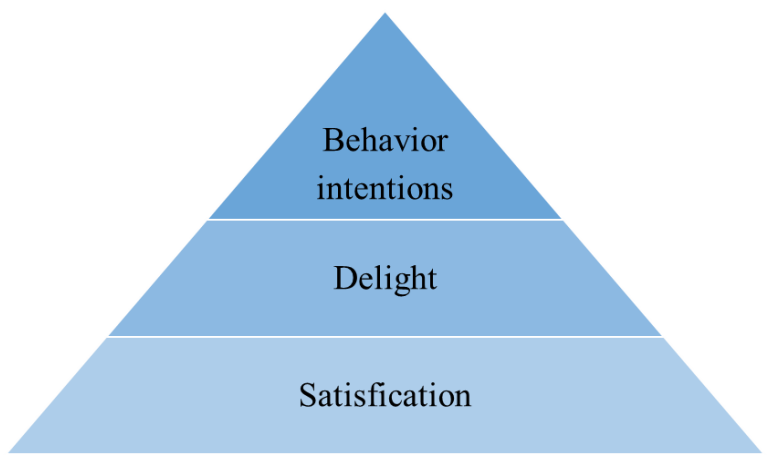

Figure 1. Conceptual model of research

\section{Research method}

This research has been studied based on descriptive-analytic and survey method has. The first part of this article, which is devoted to understanding theoretical fundamentals and literature, is possible through descriptiveanalytical and documentary methods in the library by studying books, journals, journals, etc. The second part of the study is survey and field observations. Research tool is a questionnaire. The answer spectrum is based on Likert scale from one to five $(1=$ very low, $2=$ low, $3=$ average, $4=$ high, $5=$ very high). 
Case studies are GhasrKhorshid andEmaratGorgan, which are among the most popular and most used restaurants in the city. The statistical community is also the customers of these restaurants, which according to the highest Cochran formula, 384 people have been studied. Therefore, about 400 questionnaires were distributed among clients, 200 questionnaires were distributed in Ghasrekhorshid and 200 questionnaires were displayed in the EmaratGorgan. Some of the questionnaires were removed due to incompleteness and such problems, and 384 questionnaires were prepared for analysis.

Research Model

Presenting various models on environment quality, satisfaction, delight and behavior intentions and effecting factors for these concepts, is what have been studied so far.In order to extract the theoretical model of research, first, the criteria for assessing environmental components were presented in Fig. 2. Forming theoretical model of research done by four factors of environment quality, satisfaction delight and behavior intentions. In this way, the factor of performance, accesslevels, space decoration, relationships and arrangement of physical and lighting components, and green space were classified as components of the quality of the environment) Ruy et al, 2012; Ali et al, 2016 (And their impact on satisfaction, delight andbehavior intentions of customers was measured.

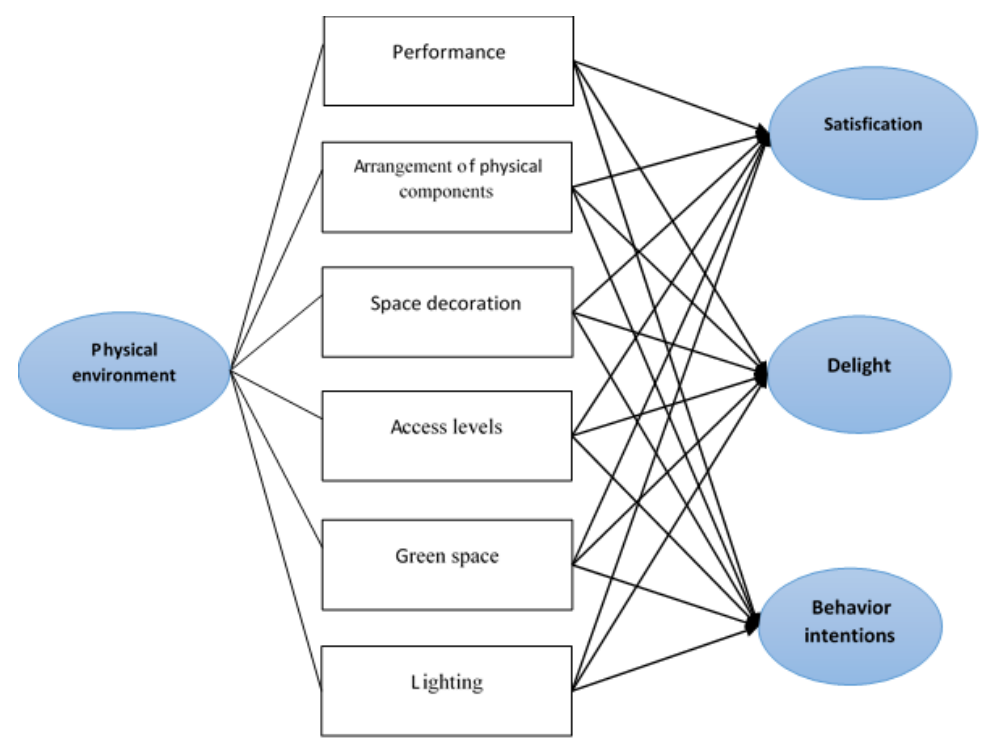

Figure 2. Theoretical model of research, factors affecting the quality of environment on satisfaction, delight and behavior intentions

As previously mentioned, this study seeks to assess the environmental quality components of satisfaction and delight and behavior intentions of customers.For this purpose, some restaurants in Gorgan were selected 
for this study. Level of satisfaction of restaurants by asking people and visual observations, and being in some of the restaurants are the keys to choose the case studies, and finally among them two was selected, GhasreKhorshid and EmaratGorgan, located in Naharkhoran road (Figure $3 \& 4$ ).

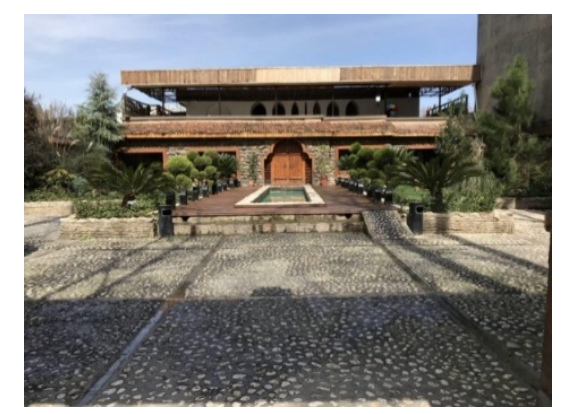

Figure 3. Emarat Restaurant (Reference: Writer)

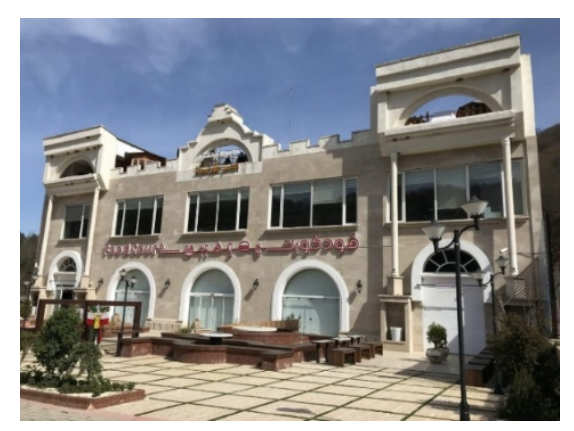

Figure 4. GhasrKhorshid Restaurant (Reference: Writer)

\section{Findings}

Datawere analyzed using descriptive and inferential statistics. In away, descriptive statistics will be used to describe the results of the statistical population. Distribution table, percentage, graphs, and average used to organize, summarize and categorizing statics, Spearman correlation and regression test in the SPSS is also used to analyze the results. Cronbach's Alpha is also used to measure reliability.

Table 1. Reliability of the variables examined

\begin{tabular}{|c|c|c|}
\hline Variable & $\begin{array}{c}\text { Number of } \\
\text { items }\end{array}$ & $\begin{array}{c}\text { Cronbach's } \\
\text { Alpha }\end{array}$ \\
\hline $\begin{array}{c}\text { environmental } \\
\text { quality }\end{array}$ & 25 & 0.97 \\
\hline satisfaction & 3 & 0.92 \\
\hline delight & 3 & 0.89 \\
\hline Behavior intentions & 3 & 0.91 \\
\hline
\end{tabular}


Cronbach's alpha for environmental quality as an independent variable among 25 items was 0.97 and for customer satisfaction as the dependent variable from 3 items, 0.92 , delight between 3 items, 0.89 , and also for the dependent variable of behavior intentions the 3 rd order is 0.91 , so all four Cronbach alpha are desirable(Table 1).

Table 2. Reliability of independent variables examined

\begin{tabular}{|c|c|c|}
\hline Variable & Number of items & Cronbach's Alpha \\
\hline green space & 5 & 0.86 \\
\hline space decoration & 5 & 0.85 \\
\hline $\begin{array}{c}\text { relationships and arrangement of physical } \\
\text { component }\end{array}$ & 3 & 0.79 \\
\hline lighting & 5 & 0.86 \\
\hline performance & 3 & 0.81 \\
\hline Accesslevels & 4 & 0.88 \\
\hline
\end{tabular}

Cronbach's alpha of each of the independent variables of environmental quality is higher than 0.7 , so the variables have a desirable reliability (Table 2).

Table 3. Correlation matrix between research variables

\begin{tabular}{|c|c|c|c|c|c|c|c|}
\hline \multicolumn{2}{|c|}{ Variable } & lighting & $\begin{array}{c}\text { relationships and } \\
\text { arrangement of } \\
\text { physical } \\
\text { component }\end{array}$ & $\begin{array}{c}\text { Space } \\
\text { decoration }\end{array}$ & $\begin{array}{c}\text { green } \\
\text { space }\end{array}$ & $\begin{array}{c}\text { Access } \\
\text { level }\end{array}$ & $\begin{array}{c}\text { Perfor- } \\
\text { mance }\end{array}$ \\
\hline satisfaction & $\begin{array}{c}\text { Pearson } \\
\text { coefficient }\end{array}$ & 0.463 & 0.410 & 0.472 & 0.482 & 0.467 & 0.454 \\
\cline { 2 - 8 } & $\begin{array}{c}\text { significance } \\
\text { level }\end{array}$ & 0.000 & 0.000 & 0.000 & 0.000 & 0.000 & 0.000 \\
\hline delight & $\begin{array}{c}\text { Pearson } \\
\text { coefficient }\end{array}$ & 0.496 & 0.455 & 0.493 & 0.500 & 0.502 & 0.502 \\
\cline { 2 - 8 } & $\begin{array}{c}\text { significance } \\
\text { level }\end{array}$ & 0.000 & 0.000 & 0.000 & 0.000 & 0.000 & 0.000 \\
\hline $\begin{array}{c}\text { Behavior } \\
\text { intentions }\end{array}$ & $\begin{array}{c}\text { Pearson } \\
\text { coefficient }\end{array}$ & 0.484 & 0.417 & 0.482 & 0.490 & 0.496 & 0.483 \\
\cline { 2 - 8 } & $\begin{array}{c}\text { significance } \\
\text { level }\end{array}$ & 0.000 & 0.000 & 0.000 & 0.000 & 0.000 & 0.000 \\
\hline
\end{tabular}

Table 3 shows that there is a significant correlation between the variables in the significance level less than one hundredth ( $\operatorname{sig}=0.000<0.01$ ).

Table 4. Model summary between research variables

\begin{tabular}{|c|c|c|c|c|c|c|c|c|c|c|}
\hline \multirow[b]{2}{*}{ Model } & \multirow[b]{2}{*}{$\mathrm{R}$} & \multirow[b]{2}{*}{$\begin{array}{c}\mathrm{R} \\
\text { Square }\end{array}$} & \multirow[b]{2}{*}{$\begin{array}{l}\text { Adjusted } \\
\text { R Square }\end{array}$} & \multirow[b]{2}{*}{$\begin{array}{l}\text { Std. Error } \\
\text { of the } \\
\text { Estimate }\end{array}$} & \multicolumn{5}{|c|}{ Change statistics } & \multirow[b]{2}{*}{$\begin{array}{l}\text { Durbin } \\
\text { watson }\end{array}$} \\
\hline & & & & & $\begin{array}{c}\mathrm{R} \\
\text { Square } \\
\text { change }\end{array}$ & $\begin{array}{c}\mathrm{F} \\
\text { Change }\end{array}$ & Df1 & Df2 & $\begin{array}{l}\text { Sig. F } \\
\text { change }\end{array}$ & \\
\hline satisfaction & .484 & .234 & .222 & .82993 & .234 & 19.206 & 6 & 377 & .000 & 1.758 \\
\hline delight & .502 & .252 & .240 & .89130 & .252 & 21.201 & 6 & 377 & .000 & 1.708 \\
\hline $\begin{array}{l}\text { Behavior } \\
\text { intentions }\end{array}$ & .505 & .255 & .243 & .88483 & .255 & 21.542 & 6 & 377 & .000 & 1.717 \\
\hline
\end{tabular}


Table 5. ANOVA between research variables

\begin{tabular}{|c|c|c|c|c|c|c|}
\hline variable & model & Sum of Square & $\mathrm{df}$ & $\begin{array}{c}\text { Mean } \\
\text { square }\end{array}$ & $\mathrm{F}$ & Sig. \\
\hline \multirow{2}{*}{ satisfaction } & Regression & 79.373 & 6 & 13.229 & 19.206 & .000 \\
\cline { 2 - 7 } & Residual & 259.673 & 377 & .689 & & \\
\cline { 2 - 8 } & Total & 339.046 & 383 & & & \\
\hline \multirow{2}{*}{ delight } & Regression & 101.053 & 6 & 16.842 & 21.201 & .000 \\
\cline { 2 - 8 } & Residual & 299.498 & 377 & .794 & & \\
\cline { 2 - 8 } & Total & 400.551 & 383 & & & \\
\hline \multirow{2}{*}{$\begin{array}{c}\text { Behavior } \\
\text { intentions }\end{array}$} & Regression & 101.197 & 6 & 16.866 & 21.542 & .000 \\
\cline { 2 - 8 } & Residual & 295.164 & 377 & .783 & & \\
\cline { 2 - 8 } & Total & 396.361 & 383 & & & \\
\hline
\end{tabular}

Table 6. Coefficients between environmental quality and satisfaction

\begin{tabular}{|c|c|c|c|c|c|c|c|c|}
\hline variable & \multicolumn{2}{|c|}{$\begin{array}{c}\text { Unstandardized } \\
\text { coefficients }\end{array}$} & $\begin{array}{c}\text { standardized } \\
\text { coefficients }\end{array}$ & \multirow{2}{*}{ Sig. } & $\mathrm{t}$ & \multicolumn{3}{|c|}{ correlations } \\
\cline { 2 - 8 } \cline { 5 - 8 } & $\mathrm{B}$ & Std.Error & Beta & & & $\begin{array}{c}\text { Zero- } \\
\text { order }\end{array}$ & partial & Part \\
\hline constant & 1.321 & .182 & & .000 & 7.251 & & & \\
\hline lighting & -.704 & .305 & -.590 & .022 & -2.305 & .434 & -.118 & -.104 \\
\hline $\begin{array}{c}\text { relationships } \\
\text { and } \\
\text { arrangement of } \\
\text { physical } \\
\text { component }\end{array}$ & -.297 & .201 & -.266 & .141 & -1.475 & .396 & -.076 & -.066 \\
\hline $\begin{array}{c}\text { space } \\
\text { decoration }\end{array}$ & .083 & .340 & .068 & .808 & .243 & .452 & .013 & .011 \\
\hline Space green & 1.404 & .457 & 1.155 & .002 & 3.071 & .460 & .156 & .138 \\
\hline Access level & .151 & .373 & .133 & .685 & .405 & .448 & .021 & .018 \\
\hline performance & -.068 & .400 & -.060 & .864 & -.171 & .437 & -.009 & -.008 \\
\hline
\end{tabular}

According to the ANOVA test, the significance level of sig is equal to $(\mathrm{sig}=0.000)$ and this value is less than $0.01(\mathrm{sig}<0.01)$. Therefore, the entire regression model is meaningful (Table 5).

The independence of independent variables, or in other words, the non-correlation of the independent variable error scores with each other is measured by the Durbin Watson test (the statistical value of this test should be between 1.5 and 2.5). The value of this statistic in the present study is 1.758 , which is the sign the witness confirms the independence of the observations (Table 4).

Based on the Coefficients table and considering the amount of sig in this table, among the six independent variables of environmental quality variable "green space" has a significant effect on customer satisfaction. This variable with weight $(1.155)$ has the most impact on customer satisfaction (Table 6).

Also, according to the value of $\mathrm{R}$, square $=0.234$, this value indicates the dependent variable variations are influenced by the independent 
variables, ie $23 \%$ of the customer delight changes are influenced by the independent variables of the environment quality of the restaurant space (Table 4).

Table 7. Coefficients between environmental quality and delight

\begin{tabular}{|c|c|c|c|c|c|c|c|c|}
\hline \multirow[t]{2}{*}{ variable } & \multicolumn{2}{|c|}{$\begin{array}{l}\text { Unstandardized } \\
\text { coefficients }\end{array}$} & \multirow{2}{*}{$\begin{array}{l}\text { standardized } \\
\text { coefficients } \\
\text { Beta }\end{array}$} & \multirow[t]{2}{*}{ Sig. } & \multirow[t]{2}{*}{$\mathrm{t}$} & \multicolumn{3}{|c|}{ correlations } \\
\hline & B & Std.Error & & & & $\begin{array}{l}\text { Zero- } \\
\text { order }\end{array}$ & partial & Part \\
\hline constant & 1.138 & .196 & & .000 & 5.815 & & & \\
\hline lighting & .464 & .328 & .358 & .158 & 1.416 & .482 & .073 & .063 \\
\hline $\begin{array}{l}\text { relationships } \\
\text { and } \\
\text { arrangement } \\
\text { of physical } \\
\text { component }\end{array}$ & -.024 & .216 & -.020 & .912 & -.110 & .451 & -.006 & -.005 \\
\hline $\begin{array}{c}\text { space } \\
\text { decoration }\end{array}$ & -.095 & .365 & -.071 & .795 & -.260 & .479 & -.013 & -.012 \\
\hline Space green & -.234 & .491 & -.177 & .634 & -.476 & .481 & -.025 & -.021 \\
\hline Access level & .184 & .400 & .149 & .646 & .459 & .493 & .024 & .020 \\
\hline performance & .336 & .430 & .271 & .435 & .781 & .495 & .040 & .035 \\
\hline
\end{tabular}

According to the ANOVA test, the significance level of sig is equal to $(\mathrm{sig}=0.000)$ and this value is less than $0.01(\mathrm{sig}<0.01)$. Therefore, the entire regression model is meaningful(Table 5).

The independence of independent variables, or in other words, the non-correlation of the independent variable error scores with each other is measured by the Durbin Watson test (the statistical value of this test should be between 1.5 and 2.5). The value of this statistic in the present study is 1.708 , which is the sign the witness confirms the independence of the observations(Table 4).

Based on the Coefficients table and according to the amount of sig in this table, among the six independent variables of environmental quality, none of the environmental quality variables have affected customer delight (Table 7).

Also, according to the value of $\mathrm{R}$, square $=0.252$, this value indicates the dependent variable variations are influenced by the independent variables, ie $25 \%$ of the customer delight changes are influenced by the independent variables of the environment quality of the restaurant space (Table 4). 
Table 8. Coefficients between environmental quality and behavior intentions

\begin{tabular}{|c|c|c|c|c|c|c|c|c|}
\hline \multirow[t]{2}{*}{ variable } & \multicolumn{2}{|c|}{$\begin{array}{l}\text { Unstandardized } \\
\text { coefficients }\end{array}$} & \multirow{2}{*}{$\begin{array}{c}\text { standardized } \\
\text { coefficients }\end{array}$} & \multirow[t]{2}{*}{ Sig. } & \multirow[t]{2}{*}{$\mathrm{t}$} & \multicolumn{3}{|c|}{ correlations } \\
\hline & B & Std.Error & & & & $\begin{array}{l}\begin{array}{l}\text { Zero- } \\
\text { order }\end{array} \\
\end{array}$ & partial & Part \\
\hline constant & 1.132 & .194 & & .000 & 5.826 & & & \\
\hline lighting & .434 & .325 & .337 & .183 & 1.333 & .475 & .068 & .059 \\
\hline $\begin{array}{l}\text { relationships } \\
\text { and } \\
\text { arrangement of } \\
\text { physical } \\
\text { component }\end{array}$ & -.218 & .214 & -.180 & .310 & -1.017 & .414 & -.052 & -.045 \\
\hline $\begin{array}{c}\text { space } \\
\text { decoration }\end{array}$ & .008 & .362 & .006 & .982 & .022 & .470 & .001 & .001 \\
\hline Space green & -.084 & .487 & -.064 & .864 & -.172 & .474 & -.009 & -.008 \\
\hline Access level & 547 & .398 & .446 & .170 & 1.375 & .496 & .071 & .061 \\
\hline performance & -.060 & .427 & -.049 & .887 & -.142 & .481 & -.007 & -.006 \\
\hline
\end{tabular}

According to the ANOVA test, the significance level of sig is equal to $(\mathrm{sig}=0.000)$ and this value is less than $0.01(\mathrm{sig}<0.01)$. Therefore, the entire regression model is meaningful(Table 5).

The independence of independent variables, or in other words, the non-correlation of the independent variable error scores with each other is measured by the Durbin Watson test (the statistical value of this test should be between 1.5 and 2.5). The value of this statistic in the present study is 1.717 , which is the sign the witness confirms the independence of the observations(Table 4).

Based on the Coefficients table and according to the amount of sig in this table, among the six independent variables of environmental quality, none of the environmental quality variables have affected customer behavior intentions (Table 8).

Also, according to the value of $\mathrm{R}$, square $=0.252$, this value indicates the dependent variable variations are influenced by the independent variables, ie $25 \%$ of the customer delight changes are influenced by the independent variables of the environment quality of the restaurant space (Table 4).

\section{Conclusion}

By human societies development and loss of meaning to the spaces in built areas, designers and environmental planners concerns about the quality of the environment and roles of environment factors in shaping different spaces. As a result, consequences of effects and relation of environment and space on human mental and behavior has been considered. Giving relaxation, satisfaction and delight in human's mind and a feeling and desire of being in a place much more is what this spaces make.This research seeks to assess the relationship between satisfaction, delight and behavior intentions and environmental quality components of the restaurant's atmosphere. The results of data analysis and quantitative data from the distribution of the questionnaire show that the most important 
environmental quality index is to use the "green space". Therefore, it is necessary to review and pay special attention to the design of the restaurant space, which plays a significant role in the tourism industry of every country. Here are some suggestions for the results of the research to improve the conditions for the construction of the physical environment of the restaurants.

\section{In this study, green space was measured by the following questions:}

1 - There are large windows with a green landscape in the lobby

2- The salon has many plants.

3- On the dining tables, there are small natural flowers.

4- Green space is used in outdoor design of the restaurant.

5- The pendant flowers and plants have been used in commuting routes.

Being in a nature, have a view of flowers and even animals in different sizes, sitting, walking among them, are a sign of people to need a nature. Researchers shows that not only being in nature, but also looking at it increases people's health, mentally, physically and even socially. Making a place lively can be achieved by bringing nature indoors, such as using small flowers, tiny animals, aquariums, watermarks and so on, which gives costumers relaxation in both resting and eating time.

\section{Reference}

1. Abolhasani, Farahnaz, Varesi, HamidReza, Darabi, Mozhgan (2011). Analysis of the role of travel agencies and restaurants in Isfahan city using Tourism Development Index, Quarterly Journal of Tourism, No. 1, pp: 83-100.

2. Ali, F, Kim, W.G, Ruy, K, (2016), The effect of physical environment on passenger delight and satisfaction: Moderating effect of national identity, Tuorism management, vol. 57, pp. 213- 224.

3. Al-Hawari, M.A, (2011), Automated service quality as a predictor of customers commitment: A practical study within the UAE retail banking context, Asia pacific journal of marketing and logistics, 23 (3), pp. 346- 366.

4. AmirShahi, Mir Ahmad, Siahtiri, Vida, Ravanbad, Fariba (2009), Identifying the Trust Factors Affecting Trust in Key Customers at the Bank of Entrepreneurship in Tehran. Management Researches in Iran, No. 4, pp: 61-76.

5. Anderson, E. W., \& Sullivan, M. W. (1993). The antecedents and consequences of customer satisfaction for firms. Marketing science

6. Brady, M. K., \& Cronin Jr, J. J. (2001). Some new thoughts on conceptualizing perceived service quality: a hierarchical approach. Journal of marketing, 65(3), 34-49.

7. Canter, D.V, (1977), The psychology of place, London: Architectural Press.

8. Caruana, A. (2002). Service loyalty: The effects of service quality and the mediating role of customer satisfaction. European journal of marketing, 36(7/8), 811-828.

9. Cutler, Philip, Armstrong, Gary(2007), Principles of Marketing(Ali Parsian), AdabestanPublication, Tehran.

10. Deng, Z., Lu, Y., Wei, K. K., \& Zhang, J. (2010). Understanding customer satisfaction and loyalty: An empirical study of mobile instant messages in China. International journal of information management, 30(4), 289-300. 
11. Dick, A. S., \&Basu, K. (1994). Customer loyalty: toward an integrated conceptual framework. Journal of the academy of marketing science, 22(2), 99-113.

12. Dozdozani, Yasmin, Etesam, Iraj, Taghizadeh, Mohammad (2015), Comparison of Satisfaction of Citizens in the Fields of the Universe, Baharestan, Del Camposa and Navona from the Design of Urban Community Sites. Urban Research and Planning, No. 21, pp: 103-120.

13. Emamgholi, Aghil, AyvazianSymon , ZadehMohammadi, Ali, Eslami, SeyedGholamreza (2012). Environmental Psychology, Common area of Architecture and Behavioral Sciences, Behavioral Sciences Journal, No. 14, pp: 23- 44.

14. Flavien, C., Guinaleu, M., \&Gurrea, R. (2006). The role played by perceived usability, satisfaction and consumer trust on website loyalty. Information \& Management, 43(1), $1-14$.

15. Galbraith, John Kent (2003), Satisfaction Culture, (Saeed Sari Aslani), Ney Publication, Tehran.

16. Gifford, R,(1999), Perception andRecognition Environmental,TranslatedDehbashy, ArchitecturalandCulturalJournal, 2-3(1), 21-29.

17. Ghiasvand, Ahmad (2011), Survey of Citizens' Satisfaction with Municipal Action to Reduce Air Pollution, Publications of Sociologists, Tehran.

18. Haghighi, Mohammad, Moghimi, Mohammad, Kimasi, Masoud (2003), The Effects of Service and Customer Satisfaction Mediator, Management Knowledge, No. 60 and 61, pp: 59-72.

19. Ha, M, Weber, M.J, (1994), Residential Quality and Satisfaction: Toward Developing Residentioal Quality Indexes, Home Economics Research journal, 22 (3): 296-308.

20. Jamal, A., \&Naser, K. (2002). Customer satisfaction and retail banking: an assessment of some of the key antecedents of customer satisfaction in retail banking. International journal of bank marketing, 20(4), 146-160.

21. J Braham, Barbara (1991). Finding your purpose : a guide to personal fufillment(JavadMontazeri\&ShahnazMontazeri). Naslenowandish, Tehran.

22. Keating, B., Rugimbana, R., \&Quazi, A. (2003). Differentiating between service quality and relationship quality in cyberspace. Managing Service Quality: An International Journal, 13(3), 217-232.

23. Keng, C. J., Huang, T. L., Zheng, L. J., \& Hsu, M. K. (2007). Modeling service encounters and customer experiential value in retailing: An empirical investigation of shopping mall customers in Taiwan. International Journal of Service Industry Management, 18(4), 349-367.

24. Ladhari, R. (2009). Service quality, emotional satisfaction, and behavioural intentions: A study in the hotel industry. Managing Service Quality: An International Journal, 19(3), 308-331.

25. Mortazavi, Shahrnaz (2001), Psychology of the environment and its application, ShahidBeheshti University Press, Tehran.

26. Mozafari, Negin, Latifi, Bita, Berkpoor, Naser, (2016), Measurement and Comparison of Satisfaction of Residents with Residential System. Case Study: Areas 3 and 11 of Tehran, Journal of Urban Studies, No. 17, pp: 77-92.

27. Nazemi, Shamsuddin, SaadatYar, Fahimeh Sadat (2013), The Role of Factors of Fame and Innovation on Restaurant Loyalty by Considering the Role of Interesses of Satisfaction and Recognized Value, Journal of Tourism Management Studies, No. 22, pp: $58-79$.

28. Oliver, R. L. (1999). Whence consumer loyalty?. the Journal of Marketing, 33-44.

29. Olson, J.C, Peter, J. P, (2000), Consumer Behavior And Marketing Strategy. NewYork: Mcgraw-HillCompanies 
30. Pandar, Hadi, Zakavat, Kamran (2015). The Emotional Process of Physical Changes in the Residential Environment from the Users' Perspectives Based on Satisfactory Criteria of the Case Study, Niavaran Neighborhood, Journal of Urban Studies, No. 17, pp: 1528.

31. Potter, J., Cantarero, R,(2006), How Does Increasing Population and Diversity Affect Resident satisfaction? A Small Community Case Study, environment and behavior, vol. 38 , no. 5 , pp. 605-625.

32. Ranjbarian, Bahram, Zahedi, Mohammad. Services in tourism industry. Kankash publication, Esfahan

33. Rafaati, Javad, Aghamousa, Reza, ZandHabibi, Kimia (2014), The Effective Factors of Customer Sentiment on Oral Advertising (Case Study: Restaurant Industry), Journal of Economics and Business, No. 6, pp: 29-45.

34. Reuland, R., Choudry, J., \&Fagel, A. (1985). Research in the field of hospitality. International Journal of Hospitality Management, 4(4), 141-146.

35. Ryu, K., Jang, S. S. (2007). The effect of environmental perceptions on behavioral intentions through emotions: The case of upscale restaurants. Journal of Hospitality \& Tourism Research, 31(1), 56-72.

36. Ryu, K., Lee, H. R., \&Gon Kim, W. (2012). The influence of the quality of the physical environment, food, and service on restaurant image, customer perceived value, customer satisfaction, and behavioral intentions. International Journal of Contemporary Hospitality Management, 24(2), 200-223.

37. Saeednia, Hamid Reza, Bahadoran, Meysam (2008), The Effect of the Company's Name and Company's Familiarity with the Customer Loyalty Process. Journal of Iran rubber. No. 51.

38. Safian, MohammadJavad, Ansari, Maedeh, Ghaffari, Ali, Masoud, Mohammad (2011), Phenomenological Study of Hermeneutics of the Position of the Site with the Art of Architecture, Philosophical Research, Tabriz University, No. 8, pp :12-93.

39. Soltani, Ali, Sharif, Hamid Reza, (2014), Satisfaction of religious tourism services with an emphasis on the role of environmental factors (Case Study Shahcheragh shrine).Journal of Urban Planning and Research, Vol. 6, No. 23, pp: 35-54.

40. Sweeney, J., \&Swait, J. (2008). The effects of brand credibility on customer loyalty. Journal of retailing and consumer services, 15(3), 179-193.

41. Torres, E.N, Kline, S, (2006), Form satisfaction to delight: A model for the industry, International journal of Contemporary Hospitality Management, 18 (4), pp. 290- 301.

42. Tsaur, S. H., Chiu, Y. T., \& Wang, C. H. (2007). The visitors behavioral consequences of experiential marketing: an empirical study on Taipei Zoo.Journal of Travel \& Tourism Marketing, 21(1), 47-64.

43. Waxman, L. K, 2004, More than coffee: an examination of people, place and community with implications for design.Ph.D. Thesis, florida state university.

44. Westbrook, R. A. (1987). Product/consumption-based affective responses and postpurchase processes. Journal of marketing research, 258-270. 